\title{
Land Surface Temperature Determination in the Town of Mostar Area
}

\author{
Tea DUPLANČIĆ LEDER, Nenad LEDER
}

\begin{abstract}
The article presents the most critical factors that affect the soil temperature, such as the effects of the canyon, anthropogenic heat, greenhouse effect, effective reflectivity, evaporating reduction and turbulent transfer of heat. Most of these factors can be found in the town of Mostar area. The simplest and the most widely used method of land surface temperature determination is processing of thermal channels satellite scenes. Landsat is the longest and most widely used satellite mission with open data. For the purposes of this study Landsat 5,7 and 8 satellite scenes were used and open meteorological data from which the atmospheric correction was calculated, and then land surface temperature (LST) for the Mostar area. Three winter scenes were used (occurred in the colder part of year) and three summer scenes (occurred in the warmest part of the year). From all processed data can be concluded that Mostar can be considered as one of the warmest towns in Bosnia and Herzegovina and wider.
\end{abstract}

Keywords: Landsat mission; Land surface temperature; remote sensing; urban heat islands

\section{INTRODUCTION}

Urbanization in the last half century and recent climate changes cause temperature balance changes in densely populated areas. These problems are addressed by urban climatology studies whose most important parameters are surface air and soil temperature [1, 2, 3] which are determined by thermal remote sensing. Urban heat island (UHI) and land cover data are very important for models above urban areas $[3,4,5]$.

UHI's are areas (most commonly urban) where the air and soil temperature are higher than the surrounding area (Fig. 1) caused by the fact that the predominant urban materials heat up differently than natural materials. Maximum air temperature in the summer period was usually observed about 16 hours [6, 7]. Highest temperatures differences have been observed in summer in cities located in lowland areas or valleys and having over 100,000 inhabitants [8]. The result of different warming of the urban and rural areas can be the temperature difference of $12{ }^{\circ} \mathrm{C}$ and more $[6,7]$.

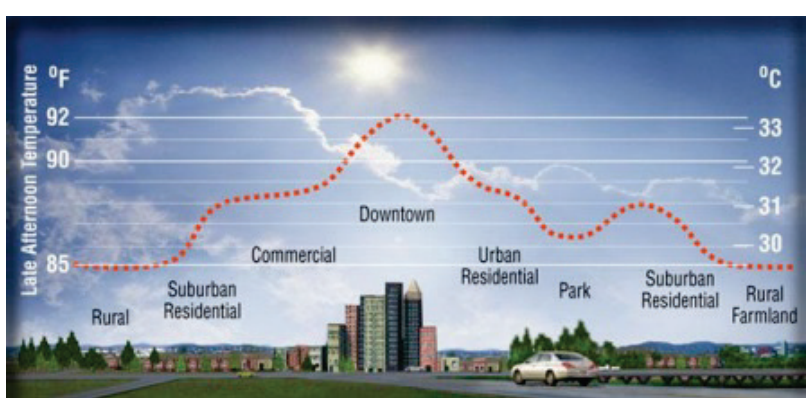

Figure 1 Urban heat island [8]

UHI are generally caused by the following [9]:

- The natural vegetation loss or replacement with evapotranspiration and humidity reduced materials;

- Dominant urban building materials with high thermal energy emission increase thermal energy storage;

- Urban geometry (urban canyons) especially in downtown;

- Vehicle exhaust, industrial areas, air conditioning equipment impact [10].
A rural area does not generally have the UHI appearance because of high evapotranspiration, large areas of shade which is created by vegetation and water areas.

The climate within urban area is quite complex, with many factors contributing to its behavior. Oke et al. [11] summarized the most critical factors affecting the formation of urban heat island within urban areas:

- Canyon geometry caused by high buildings that tend to trap thermal energy in bottom layers;

- Thermal properties of urban materials (concrete, asphalt) absorb and retain more thermal energy than natural surface cover;

- Anthropogenic heat is released from the combustion of fuels, electrical energy and human and animal biological metabolism. It can significantly increase the temperature in dense urban areas;

- The urban greenhouse effect - warmer air and air pollution within cities acts as a micro greenhouse effect, preventing heat from radiating from the warmed surfaces;

- The effective reflectivity (albedo) is reduced due to short-wave radiatiotrapping in building canyons;

- Evaporating surfaces reduction due to the reduced natural vegetation resulting in loss of moisture and adversely affecting temperatures within the city;

- Turbulent transfer heat reduction causing blocked wind patterns in some city areas, causing pockets with little wind flow and mixing. This reduced air mixing significantly reduces the heat released from streets.

The concept of urban heat fluxes introduces relatively new ideas on how anthropogenic heat emissions can be observed from space. These observations get new insights on anthropogenic heat emission detection and monitoring. These pieces of information are a significant and valuable tool for estimating the Urban Energy Budget (UEB) parameters (Eq. 1) which quantify the anthropogenic heat flux from vehicular emissions, space heating and cooling of buildings, industrial processing and the metabolic heat release by people.

The urban surface energy budget is defined as:

$Q^{*}+Q_{\mathrm{F}}=Q_{\mathrm{H}}+Q_{\mathrm{E}}+\Delta Q_{\mathrm{S}}+\Delta Q_{\mathrm{A}}+S$ 
where $Q_{\mathrm{F}}$ is the anthropogenic heat flux, $Q^{*}$ is the net allwave radiation flux, $Q_{\mathrm{H}}$ is the turbulent sensible heat flux and $Q_{\mathrm{E}}$ is the latent heat flux, $\Delta Q_{\mathrm{S}}$ is the heat storage, $\Delta Q_{\mathrm{A}}$ $=Q_{\text {in }}-Q_{\text {out }}$ and $S$ represents all other sources and sinks, within the control volume [12] shown in Fig. 2.

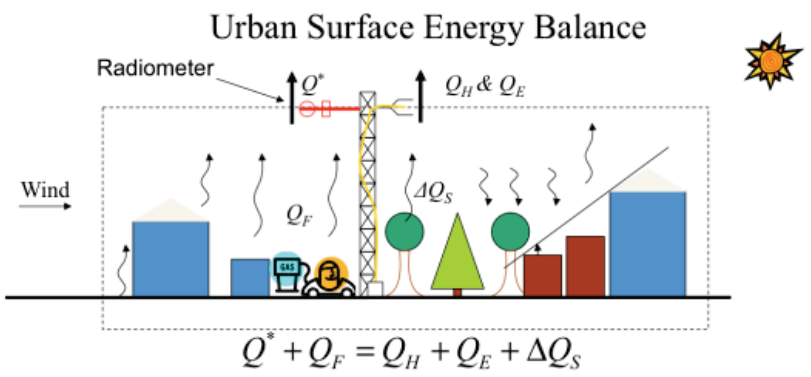

Figure 2 Urban surface energy balance fluxes [13]

Over the last decade, there has been a large amount of scientific papers and studies that monitor climate change, and especially those about risk reduction and adaptation to climate change. Most of the studies result in hazards and risk, so this work can serve as a good foundation for the development of risk assessment and environment protection from heat disasters.

The main goal of this paper is to investigate microclimatic changes at the land surface temperature (LST), as well as the existence of UTO and their temporal and seasonal variability in the area of Mostar (the hottest city of the region, located in the deep valley) in the early $21^{\text {st }}$ century (from 1999 to 2015 ) by applying the satellite remote sensing method and explaining their cause. As far as the authors are informed, the satellite remote sensing method is for the first time used to determine LST in the wider area of Mostar.

Thermal shocks are becoming more frequent and they affect the quality of life and human health (cardiovascular risk, allergic reactions and infectious diseases). Vulnerable groups are the impoverished and the elderly population. At the same time, as a result of drought, the economy falls (reducing the production of electricity and yield in agriculture and forestry) [7].

The results of the research should point out the mistakes in planning the affected and critical heat zones and be a guide to reduce the surface air temperature and soil temperature.

\section{STUDY AREA}

Bosnia and Herzegovina $(\mathrm{B} \& \mathrm{H})$ is located in Southeastern Europe, in the Western Balkans. The Herzegovina-Neretva Canton, the southern part of the country, occupies $4.401 \mathrm{~km}^{2}$ or $16.9 \%$ of the area [14], so it is the second largest Canton in B\&H. The Canton mainly comprises the river Neretva valley area and parts of Herzegovina west of Mostar, its administrative centre (Fig. 3).

In the Herzegovina-Neretva Canton the following towns are situated: Ravno, Neum, Čitluk, Stolac, Čapljina, Mostar, Jablanica, Prozor-Rama and Konjic [14]. The largest town in the Canton and the fifth largest town in the state is Mostar, located on the banks of the river Neretva (Fig. 4), and known for its Old Bridge (Stari most).
Bosnia and Herzegovina is the mostly mountainous area and belongs to the western part of the Mediterranean zone under chained mountains. Herzegovina territory has hilly and mountainous relief, with numerous depressions and basins. Of the total $\mathrm{B} \& \mathrm{H}$ area to $200 \mathrm{~m}$ height is covered $15 \%$ area, from 200 to $500 \mathrm{~m}$ about $29 \%$, from 500 to $1.000 \mathrm{~m}$ about $31 \%$, from 1000 to $1500 \mathrm{~m} 21 \%$ and from 1.500 to $2.000 \mathrm{~m}$ about $4 \%$ [15] (Fig. 5).

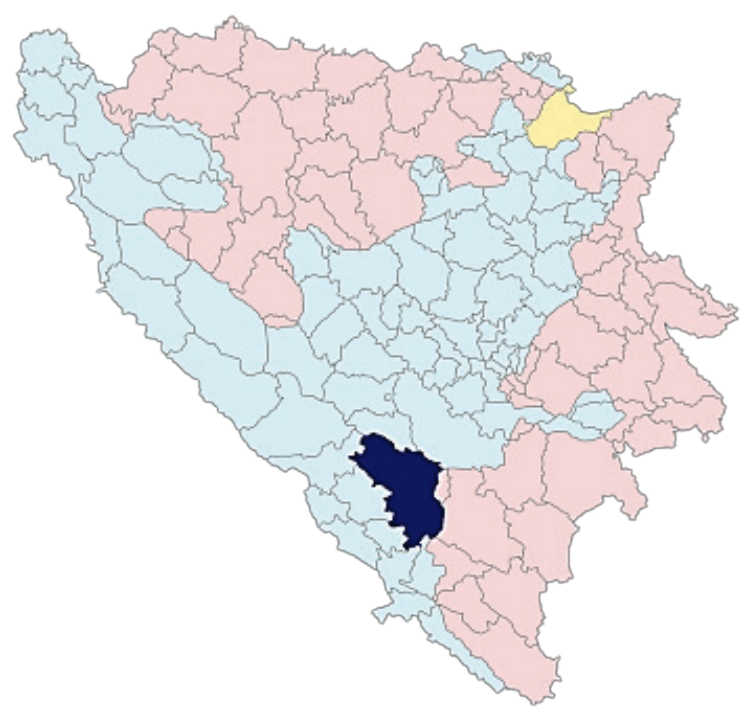

Figure 3 Location of the town of Mostar inBosnia and Herzegovina

Mostar is the town and the municipality of the southern part of B\&H with 113,169 residents [14]. It is cultural capital and the center of the Herzegovina-Neretva Canton of the B\&H. Human settlements on the river Neretva, between the Čabulja and the Velež Mountain (Fig. 4) exist from prehistory.

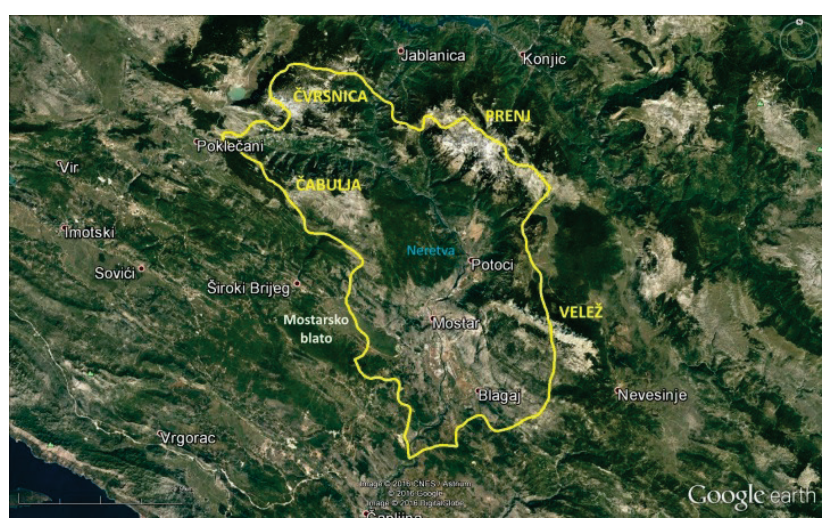

Figure 4 Location of the administrative area of the town of Mostar

\subsection{Town of Mostar Climate}

Climate characteristics of the town of Mostar are significantly under the influence of vicinity of the Adriatic Sea, with which it is connected across the river Neretva canyon. The summer air temperatures in Mostar in the last two decades were very often over $40{ }^{\circ} \mathrm{C}$ and the measured maximum was $46.2{ }^{\circ} \mathrm{C}$. The annual course of air temperature indicated that the coldest month is January (about $5^{\circ} \mathrm{C}$ on average), while the warmest is July (about $26{ }^{\circ} \mathrm{C}$ on average). Mostar climate is characterized by a period of relatively dry weather from June to September while the rest of the year is wet and mild [16]. 


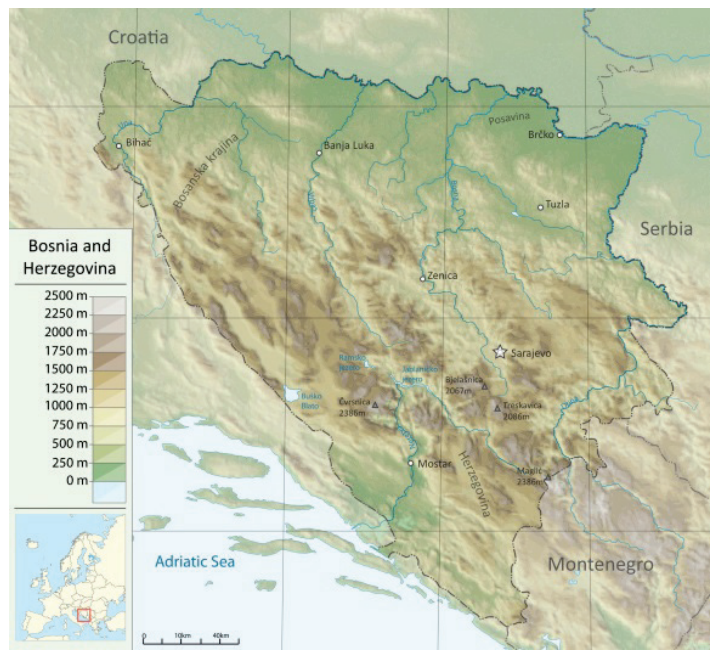

Figure 5 FB\&H elevation map; according to NASA Shuttle Radar Topography Mission (http://www.lahistoriaconmapas.com/)
According to the Köppen Climate Classification System, climate subtype for Mostar is Cfa, close to Csa subtype ("Oceanic climate with hot summers and Mediterranean tendency") [17]. With an average of 2291 solar hours per year, Mostar is the sunniest town in Bosnia and Herzegovina [18].

The highest temperature ever recorded in Mostar was on the $31^{\text {st }}$ July 1901 , and it was $46.2{ }^{\circ} \mathrm{C}$ [18]. Because of that Mostar was the warmest town in the ex-Yugoslavia, and today in B\&H. Generally, it can be concluded that it was a certain dry climate, which today is getting wetter and wetter. That makes summer heats unbearable for people [16].

Tab. 1 represents climate data for the town of Mostar for time interval from 1961 to 1990 , and extremes from 1949 to present.

Table 1 Climate data for town of Mostar (time interval from 1961 to 1990), [19-21

\begin{tabular}{|c|c|c|c|c|c|c|c|c|c|c|c|c|c|}
\hline \multicolumn{2}{|c|}{ Month } & Jan & Feb & Mar & Apr & May & Jun & Jul & Aug & Sep & Oct & Nov & Dec \\
\hline \multirow[t]{5}{*}{ Average } & $\operatorname{High}^{\circ} \mathrm{C}$ & 8.4 & 10.8 & 14.6 & 19.0 & 24.0 & 27.6 & 31.1 & 30.8 & 26.9 & 21.0 & 14.5 & 9.7 \\
\hline & Low ${ }^{\circ} \mathrm{C}$ & 1.9 & 3.2 & 5.4 & 8.4 & 12.5 & 15.8 & 18.6 & 18.4 & 15.3 & 11.2 & 6.7 & 3.3 \\
\hline & Rain days & 13 & 12 & 12 & 13 & 12 & 12 & 7 & 8 & 8 & 11 & 13 & 13 \\
\hline & Precipi. (mm) & 165 & 151 & 150 & 127 & 102 & 78 & 43 & 74 & 96 & 151 & 200 & 179 \\
\hline & Humidity (\%) & 67 & 63 & 62 & 62 & 64 & 61 & 53 & 53 & 60 & 68 & 69 & 68 \\
\hline \multirow[t]{2}{*}{ Mean } & Daily ${ }^{\circ} \mathrm{C}$ & 5.2 & 7.0 & 10.0 & 13.7 & 18.7 & 21.7 & 24.9 & 24.6 & 21.1 & 16.1 & 10.6 & 6.5 \\
\hline & Sunshine (h) & 113 & 118 & 155 & 174 & 223 & 252 & 323 & 296 & 230 & 178 & 124 & 114 \\
\hline \multirow{2}{*}{$\begin{array}{c}\text { Temp. } \\
\text { Record }\end{array}$} & $\operatorname{High}^{\circ} \mathrm{C}$ & 18.2 & 25.0 & 27.6 & 31.5 & 35.6 & 41.2 & 43.0 & 43.1 & 38.8 & 32.5 & 25.5 & 19.4 \\
\hline & Low ${ }^{\circ} \mathrm{C}$ & -10.9 & -9.6 & -6.5 & -1.2 & 3.3 & 8.0 & 8.4 & 9.6 & 6.4 & -0.1 & -4.8 & -7.8 \\
\hline
\end{tabular}

\section{MATERIALS AND METHODS}

Thermal satellite sensors used for land surface temperature determination [22] have the following characteristics or spatial and temporal resolution:

1) $\operatorname{GOES}(4 \mathrm{~km}-15 \mathrm{~min})$;

2) $\operatorname{AVHRR}(1.1 \mathrm{~km}$ - twice a day);

3) MODIS (1 km - 1-2 days);

4) Landsat $\left(120 / 60 \mathrm{~m}-16\left(8\right.\right.$ on $\left.45^{\circ}\right)$ days) $[29,30]$;

5) $\operatorname{ASTER}(90 \mathrm{~m}-16$ days).

The first remote sensing UHI observation was published in 1972 [23]. Since then, different satellite sensors and techniques were used for urban area land surface temperature observation. For the purposes of land surface temperature determination in this article Landsat satellite data were selected, because they have a good spatial resolution and they are available for use free of charge. All other satellite missions have better temporal, but worse spatial resolution, so their use is less suitable for the realization of basic objective of this study.

Landsat satellite mission has time constraints for surface land temperature determination. Problem is in the fact that satellite is above research area every eight days in 9:42 hour (UTC), while the period of day with maximum surface temperature is from 14 to 18 hours $[7,17]$. Landsat 7 Enhanced Thematic Mapper Plus Thermal infrared (ETM+ TIR) data have seven spectral channels, of which Band 6 records emitted energy in the thermal infrared part of the spectrum (10.40 to $12.50 \mathrm{~nm}$ ), and is used for studies of local scales UHI [22]. Pixel spatial resolution on band 6 is $120 \mathrm{~m}$ and $60 \mathrm{~m}$. Other channels have a spatial resolution of $30 \times 30 \mathrm{~m}$ per pixel. Landsat 8 has two main sensors: Operational Land Imager (OLI; visible, near IC and medium IC) and Thermal Infrared Sensor (Thermal IC TIR) with resolution of $100 \mathrm{~m}$. Landsat8/TM data recorded study area in 9:42 (UTC).

Landsat 7 and 8 satellites directly measure Top of the atmosphere - TOA radiance [4] in a very narrow shortwave spectral band $(0.2-5 \mu \mathrm{m})$ and the long wave spectral band (5-100 $\mu \mathrm{m})$ of electromagnetic radiation, which covers approximately $99.5 \%$ of total thermal energy emitted from the Earth. The procedure of land surface temperature calculation is reviewed in chapter 3.3. and is very similar to the methods applied to the Split Metropolitan area [24].

\subsection{Landsat Satellite Images Selection and Processing}

United States Geological Survey's Earth Resources Observation and Science Centre (USGS EROS) (http://earthexplorer.usgs.gov/) distributes standard Landsat products, which contain roughly processed and calibrated (geocoded) multispectral images. For the purposes of this study two Landsat $8 \mathrm{OLI} / \mathrm{TIR}$ scenes, recorded on the $13^{\text {th }}$ August and the $3^{\text {rd }}$ December 2015, two Landsat 5 TM scenes recorded on the $18^{\text {th }}$ August 2011 and the $5^{\text {th }}$ December 2010 and Landsat ETM+ scenes, recorded on the $16^{\text {th }}$ January 2000 and the $9^{\text {th }}$ August 1999 were selected. These scenes were chosen to represent characteristic winter and summer meteorological episodes (assumption is the largest temperature range) at the beginning of start of Landsat 7 mission (the new millennium), ten years later and the year 2015, which was declared by World Meteorological Organization [25] as the warmest year since measurements exist.

Landsat scenes were pre-processed and processed by using ArcGIS 10.3 program. Landsat satellite scenes were resampling by cubic convolution method, so as to be 
oriented to the north and georeferenced in the projection coordinate system of Universal Transverse Mercator Projection (UTM 34N) on rotational ellipsoid WGS84 (EPSG: 32633) and stored in GeoTIFF format. Landsat 7 and 8 scenes in USGS EROS archives are available to all users free and without any limitation. Final processing of obtained raster maps and data was edited in Adobe Photoshop CS6 program.

\subsection{Normalized Difference Vegetation Index}

Normalized difference vegetation index (NDVI) quantifies vegetation by measuring the difference between near-infrared (NIR; which vegetation strongly reflects) and visible red wavelength energies $(R$; which vegetation absorbs) [11]. NDVI is calculated on a per-pixel basis as the normalized difference between the red $(R)$ and near infrared $(N I R)$ bands from an image. Written mathematically, the formula for NDVI is (Eq. 2):

$$
N D V I=\frac{(N I R-R)}{(N I R+R)}
$$

$N D V I$ always ranges from -1 to +1 . High $N D V I$ values indicate healthy vegetation while low values indicate less or no vegetation.

\subsection{Atmospheric Correction}

Before satellite images processing, pre-processing was made, which includes scene atmospheric scattering elimination. As it is well known, Landsat TM, ETM+ and TIR provide high spatial thermal infrared image resolution of the Earth's surface (each pixel of scene) based on radiance of the Top of the atmosphere (TOA), which does not include atmospheric correction. For parameters of atmospheric correction calculation, atmospheric transmission and upwelling and downwelling radiance should be known or modelled for a particular area.

Method of determining atmospheric parameters based on target temperature, pressure and humidity was used. Atmospheric correction for the location of Mostar, selected the date and time, was calculated using a model that uses global atmospheric profiles, modelled by National Centres for Environmental Prediction (NCEP) [26]. This method roughly defines parameter of atmospheric correction.

Once global atmospheric temperature profile was modelled, and the land surface temperatures were determined, by knowing pressure and relative humidity, it is possible to convert the incoming spatial in outgoing spatial radiation according to Eq. (3):

$$
L_{\mathrm{TOA}}=\tau \varepsilon L_{T}+L_{\mathrm{u}}(1-\varepsilon) L_{\mathrm{d}}
$$

where $\tau$ is the atmospheric transmission, $\varepsilon$ is the emissivity of the surface, $L_{T}$ is radiance of a blackbody target of kinetic temperature $T, L_{\mathrm{u}}$ is the upwelling of atmospheric path radiance, $L_{\mathrm{d}}$ is the downwelling or sky radiance, and $L_{\mathrm{TOA}}$ is the space-reaching or TOA radiance measured by the instrument. Radiance is in units $\mathrm{W} /\left(\mathrm{m}^{2} \cdot \mathrm{ster} \cdot \mu \mathrm{m}\right)$, and the transmission and emissivity are unitless.
Radiance to temperature conversions can be made by Planck equation. Details of atmospheric correction calculations are shown in $[27,28]$. Atmospheric correction ignoring can result with systematic errors in the prediction of the land surface temperature. It should be noted that the calculated land surface temperature without NCEP atmospheric profile models for atmospheric correction calculation, can be lower up to $5-10{ }^{\circ} \mathrm{C}$ [26].

Surface meteorological parameters from the Mostar meteorological station, as well as atmospheric correction parameters (atmospheric transmission and upwelling and dowelling radiance) for selected dates and times are shown in Tab. 2. In Tab. 2 air temperatures are shown measured at the Mostar meteorological station. It can be seen that on the same dates land surface temperature is typically less than the air temperature in cold part of the year, while in summer land surface temperature is significantly higher than air temperature in mid-day period (14 hour) reaching the value of over $50{ }^{\circ} \mathrm{C}$. High temperatures of air and soil, especially those above $36^{\circ} \mathrm{C}$ can negatively affect human health, because those temperatures disable body cooling.

\subsection{Digital Number Conversion into Temperature 3.4.1 Digital Number Conversion to TOA Radiance}

OLI and TIRS band data must be converted to TOA spectral radiance according to Eq. (4) using the radiance rescaling factors provided in the metadata file [29]:

$$
L_{\lambda}=M_{\mathrm{L}} Q_{\text {cal }}+A_{\mathrm{L}}
$$

where $L_{\lambda}$ is TOA spectral radiance $\left(\mathrm{W} /\left(\mathrm{m}^{2} \cdot \operatorname{srad} \cdot \mu \mathrm{m}\right)\right) ; M_{\mathrm{L}}$ is band-specific multiplicative rescaling factor from the metadata; $A_{\mathrm{L}}$ is band-specific additive rescaling factor from the metadata; $Q_{\text {cal }}$ is quantized and calibrated standard product pixel values digital number $\mathrm{DN}$.

\subsubsection{Conversion to TOA Reflectance}

OLI band data can also be converted to TOA planetary reflectance by using reflectance rescaling coefficients provided in the product metadata file (MTL file). The following Eq. (5) is used to convert DN values to TOA reflectance for OLI data as the following:

$\rho_{\lambda}^{\prime}=M_{\rho} Q_{\mathrm{cal}}+A_{\rho}$

where $\rho_{\lambda}^{\prime}$ is TOA planetary reflectance, without correction for solar angle; $M_{\rho}$ is band-specific multiplicative rescaling factor from the metadata; $A_{\rho}$ is band-specific additive rescaling factor from the metadata; $Q_{\text {cal }}$ is quantized and calibrated standard product pixel values $\mathrm{DN}$.

\subsubsection{TOA Reflection with a Correction for the Solar Angle}

TOA with a correction for the solar angle (Eq. 6) is:

$\rho_{\lambda}=\frac{\rho_{\lambda}^{\prime}}{\cos \theta_{\mathrm{SZ}}}=\frac{\rho_{\lambda}^{\prime}}{\cos \theta_{\mathrm{SE}}}$ 
where $\rho_{\lambda}$ is TOA planetary reflectance; $\theta_{\mathrm{SE}}$ is local sun elevation angle. The scene centre sun elevation angle in degrees is provided in the metadata; $\theta_{\mathrm{SZ}}$ is local solar zenith angle; $\theta_{\mathrm{SZ}}=90^{\circ}-\theta_{\mathrm{SE}}$.

For more accurate reflectance calculations, per pixel solar angles could be used instead of the scene centre solar angle, but per pixel solar zenith angles are currently not provided with the Landsat 8 products.

\subsubsection{Conversion to At-Satellite Brightness Temperature}

Temperature radiance conversion must be performed with Planck equation [30]. TIRS band data must be converted from spectral radiance to brightness temperature (Eq. 7) using the thermal constants provided in the metadata file:

$$
T=\frac{K_{2}}{\ln \left(\frac{K_{1}}{L_{\lambda}}+1\right)}
$$

Where: $T$ is at-satellite brightness temperature $(\mathrm{K}) ; L_{\lambda}$ is TOA spectral radiance $\left(\mathrm{W} /\left(\mathrm{m}^{2} \cdot \mathrm{srad} \cdot \mu \mathrm{m}\right)\right), K_{1}$ and $K_{2}$ are band-specific thermal conversion constants from the metadata $K_{1}=666.09$ and $K_{2}=1282.71$ for Landsat 7 data, while for Landsat 8 (for band 10) are $K_{1}=774.88$ and $K_{2}=$ 1321.08 .

\subsection{Scene Classification}

There are two thermal channels on Landsat 8 satellite and both have a spatial resolution of $120 \mathrm{~m}$. Thermal channel 11 according to Landsat operating manual has calibration uncertainties, so, this study has used only a thermal channel 10.

From the study area, clouds have been "masked", if they have been observed. Unsupervised classification has been used because it is more readable than supervised, because scenes in different seasons/specific dates have different temperature ranges.

Table 2 The default meteorological parameters and calculated atmospheric correction for Mostar area $\left(43.82^{\circ} \mathrm{N}, 18.33^{\circ} \mathrm{E}\right.$, elevation $\left.51.1 \mathrm{~m}\right)$ for selected dates in $9: 42 \mathrm{UTC}$

\begin{tabular}{|c|c|c|c|c|c|c|}
\hline \multirow[b]{2}{*}{$\begin{array}{l}\text { Mostar } \\
\text { Date }\end{array}$} & \multicolumn{3}{|c|}{ Meteorological parameters } & \multicolumn{3}{|c|}{ Atmospheric correction } \\
\hline & Air temperature $\left({ }^{\circ} \mathrm{C}\right)$ & Humidity (\%) & Pressure (mb) & $\begin{array}{l}\text { Atmospheric } \\
\text { transmission }\end{array}$ & Upwelling radiance & $\begin{array}{c}\text { Downwelling } \\
\text { radiance }\end{array}$ \\
\hline $13^{\text {th }}$ August 2015 & 29.1 & 40 & 1013 & 0.69 & 2.57 & 4.14 \\
\hline $3^{\text {th }}$ December 2015 & 5.0 & 71 & 1031 & 0.94 & 0.39 & 0.67 \\
\hline $18^{\text {th }}$ August 2011 & 28.8 & 42 & 1015 & 0.76 & 1.95 & 3.15 \\
\hline $5^{\text {th }}$ December 2010 & 8.0 & 57 & 1020 & 0.94 & 0.35 & 0.61 \\
\hline $16^{\text {th }}$ January 2000 & 3.0 & 40 & 1023 & 0.93 & 0.36 & 0.62 \\
\hline $9^{\text {th }}$ August 1999 & 30.1 & 43 & 1012 & 0.73 & 2.17 & 3.51 \\
\hline
\end{tabular}

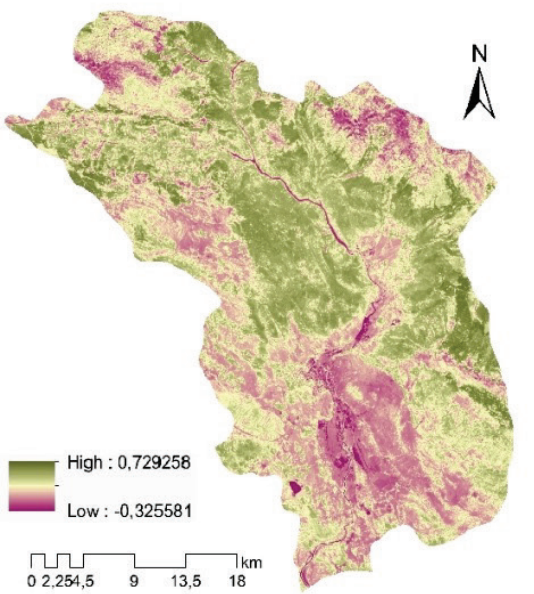

Landsat summer scene NDVI

Figure 6 The summer scene NDVI on 9th August 1999 (left), $18^{\text {th }}$ August 2011 (centre) and 13th August 2015 (right), Mostar area

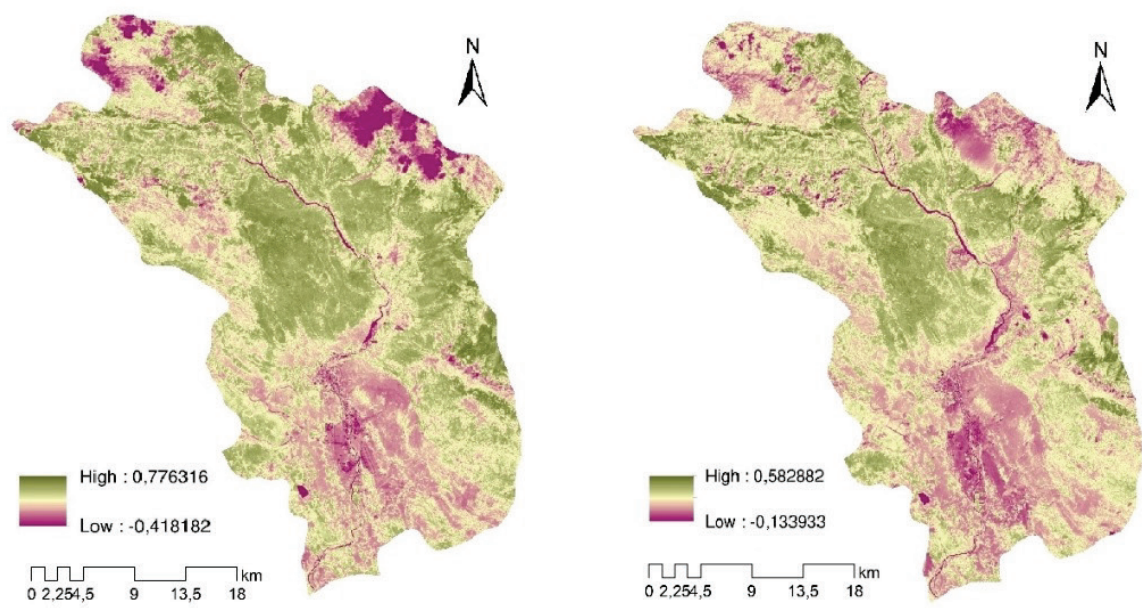

\section{RESULTS AND DISCUSSION}

Three summer and three winter scenes are compared side by side; in time intervals from 5 to 10 years. Scenes were chosen to represent the coldest (December and January) and the warmest (August) part of the year in the observed area. Unfortunately, the observed scenes were not able to be lined up equally throughout the time interval, because of freely available meteorological information, poor availability of older scenes and errors on Landsat 7 sensors, which lower the quality of data (it is especially related to thermal data which are very unstable for interpolation and unsafe for usage).
However, with comparison of these three images, very noticeable differences in the vegetation amounts and temperature ranges can be visible in this area. In Fig 6, normalized differentiated vegetation index (NDVI) is shown for three chosen summer scenes. It can be seen that in wider area of town of Mostar (southern part of area) and in the Prenj mounting area (north-eastern part of area) NDVI is low indicating that there is low amount of vegetation. This fact has a significant influence on reflection in the thermal part of spectrum (Fig 7) so in town area the highland surface temperatures have been observed [31]. In mounting area it is not so evident because of high heights. 
Fig. 7 presents summer land surface temperatures (LST) derived from the reflectance on the thermal channel 10 , calibrated to atmospheric corrections and calculated according to the meteorological data (Tab. 2). On the right side of Fig. 7 (13 ${ }^{\text {th }}$ August 2015) the highest temperature ranges can be noticed $\left(0.7-54.5^{\circ} \mathrm{C}\right)$, as a result of climate change in recent years. Landsat satellite over this area passes a few minutes before $10 \mathrm{AM}$, and the temperature maxima can be expected from $12 \mathrm{AM}$ to 4 PM. It would mean that the certain temperatures should be added from 2 to $3{ }^{\circ} \mathrm{C}$, to obtain the maximum daily temperature, which in the case of year 2015 would mean from 56 to $57^{\circ} \mathrm{C}$.

At the end of the millennium in the summer part of the year $\left(9^{\text {th }}\right.$ August 1999$)$, the temperature ranges from 8.7 to $35.7^{\circ} \mathrm{C}$. On the $18^{\text {th }}$ August 2011 , the Prenj mountain was probably still full of snow or low clouds and measured temperature was $-1.9^{\circ} \mathrm{C}$, while temperature in urban area amounted to $48{ }^{\circ} \mathrm{C}$. In 2015 , which was declared as the warmest year since the measurements exist, the lowest temperature that can be determined is $0.7^{\circ} \mathrm{C}$, while the maximum temperature reached $54.5^{\circ} \mathrm{C}$ (Fig. 7).

\section{Landsat summer scene Land Surface Temperature}
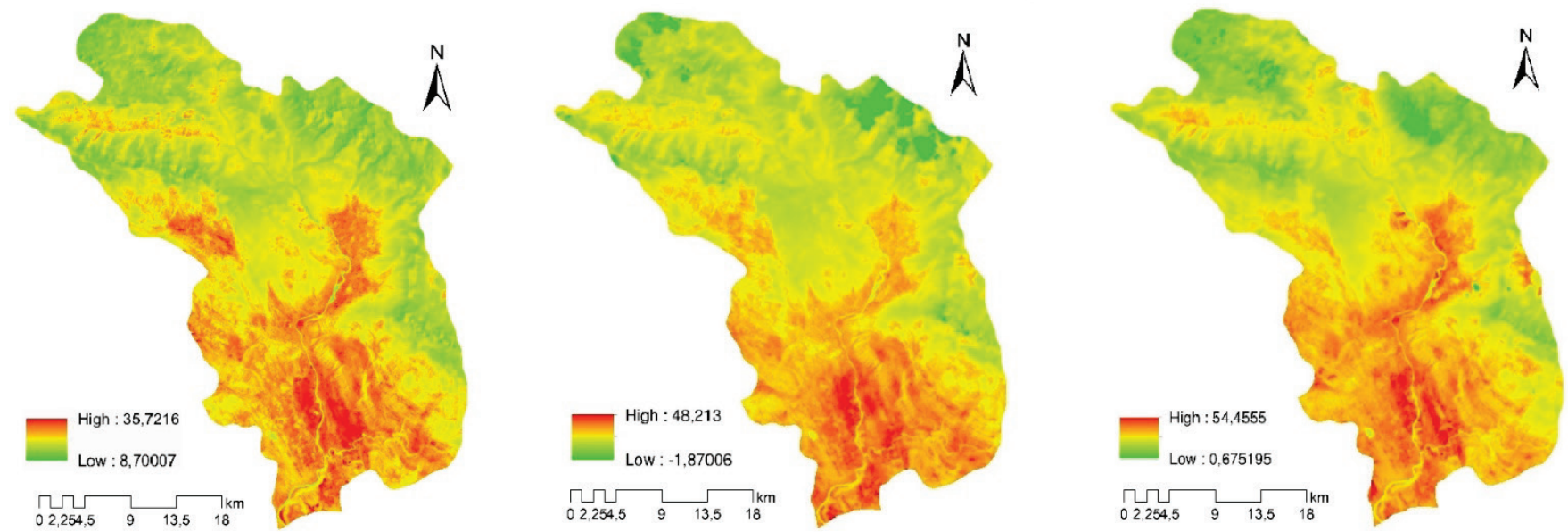

Figure 7 The summer scene LST on $9^{\text {th }}$ August 1999 (left), $18^{\text {th }}$ August 2011 (centre) and $13^{\text {th }}$ August 2015 (right), Mostar area

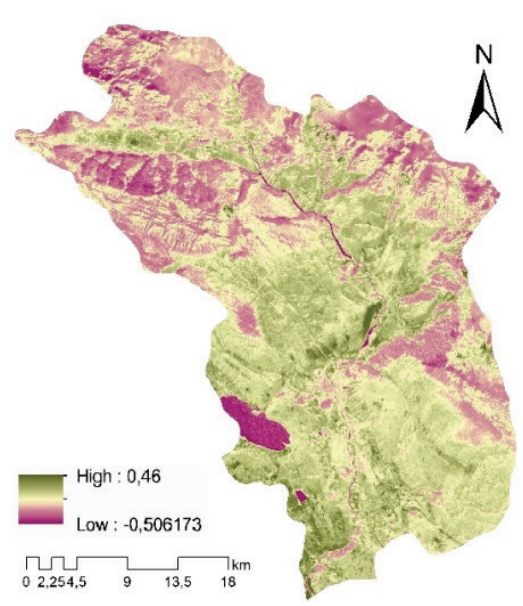

\section{Landsat winter scene NDVI}
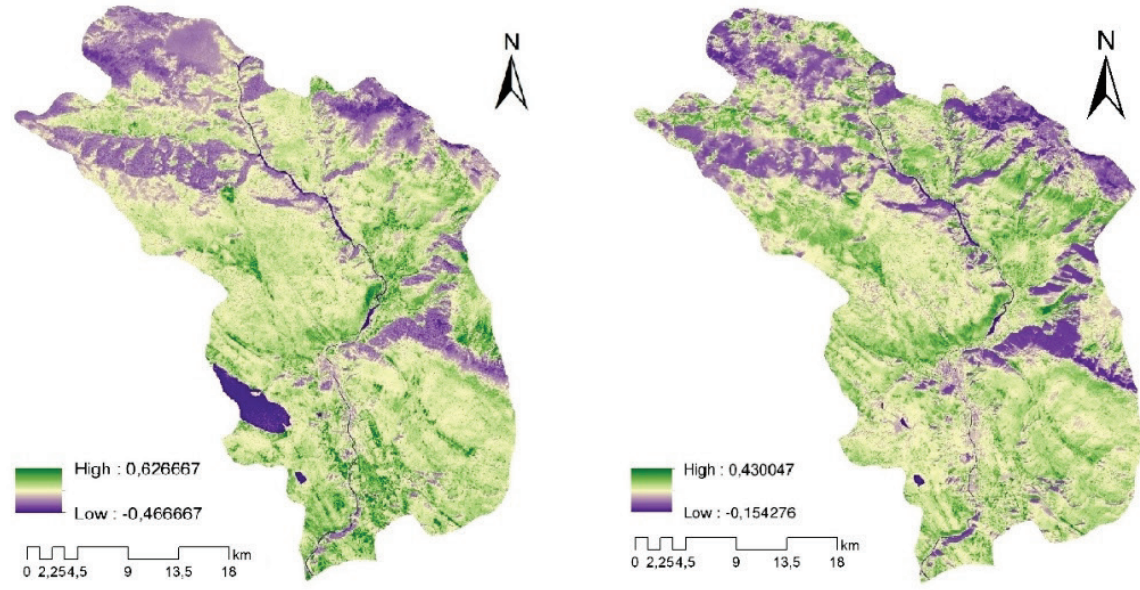

Figure 8 The winter scene NDVI on 16 $6^{\text {th }}$ January 2000 (left), $5^{\text {th }}$ December 2010 (centre) and $3^{\text {th }}$ December 2015 (right), Mostar area

NDVI of winter scenes are significantly different from those of the summer one. On the $16^{\text {th }}$ January 2000 and the $5^{\text {th }}$ December 2010 scenes, low vegetation index can be seen in the south-western part of the area, which represents the flooded area of Mostarsko blato. Likewise, on Čabulja mountain in north-western part of scene 2000, there is an area which was later covered by vegetation and it can be assumed that the area was affected by fire or in some other way left without vegetation (covered by snow) (Fig. 8).

It can be seen that temperature ranges are also more significantly differently distributed in winter season than in summer one (Figs. 7 and 9). At the beginning of the millennium in 2000 the minimum temperature was -5.9 and maximum amounted to $13.0{ }^{\circ} \mathrm{C}$. Ten years later, also in the coldest period of the year, minimum recorded temperature was $-15.0^{\circ} \mathrm{C}$ and maximum was $13.1^{\circ} \mathrm{C}$. The largest temperature range was recorded on the $3^{\text {th }}$ December 2015, from $-21.1{ }^{\circ} \mathrm{C}$ (refers to the lowest temperature of the unmasked clouds on the north-western part of the study area over the Čabulja and Čvrsnica mountain area), to maximum which amounted to $20.1{ }^{\circ} \mathrm{C}$ (Fig. 9).

The highest temperature in the summer period was recorded on urbanized area of the Mostar town basin (54.5 ${ }^{\circ} \mathrm{C}$ ), and the lowest temperature was observed in the winter period $\left(-23.1^{\circ} \mathrm{C}\right)$ on the top of the mountain Prenj.

Finally, it can be pointed out that the Neretva river can be seen in all presented NDVI and LST scenes. In winter part of the year, the river is warmer while in summer time it is colder than surroundings. 

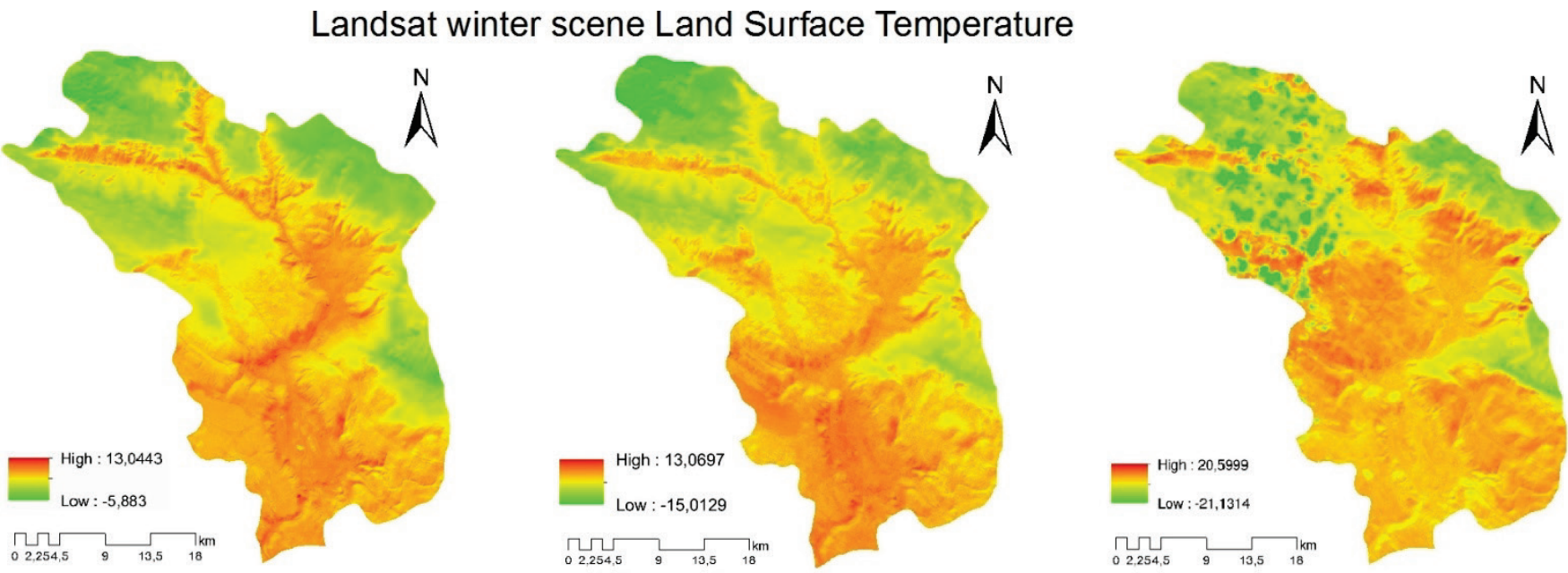

Figure 9 The winter scene LST on $16^{\text {th }}$ January 2000 (left), $5^{\text {th }}$ December 2010 (centre) and $3^{\text {th }}$ December 2015 (right), Mostar area

\section{CONCLUSION}

The method of using satellite thermal channels sensors to determine land surface temperature (LST) was often used for scientific research as well as for planning and land management. This method is used for the first time for LST and UHI of the Mostar area determining.

This paper proved that Mostar, the town where the maxima air temperatures were measured is also the town were maxima surfaced land temperatures can be expected. The town of Mostar is probably the hottest in B\&H [18] and beyond (the hottest area of the Western Balkans) because it is located in a valley or canyon in sub-Mediterranean area, which increases accumulation of heat energy. Outside of the town of Mostar, a significant part of the mountainous terrain is very sloped with a small amount of vegetation, which also increases the emission of the infrared thermal radiation.

It can be pointed out that LST greater than $50{ }^{\circ} \mathrm{C}$, which are recorded in this study in the town of Mostar, can have a very negative effect on human health.

Changes in land surface temperature in the wider area of the town of Mostar during the early $21^{\text {st }}$ century (by 2015) can most probably be explained by global climate change as well as by local influences such as the reduction of vegetation and/or construction interventions that significantly disturb the natural energy balance.

Finally, it can be concluded that this study may help urban and spatial planners to take care during the process of area planning to reduce thermal impact with applying proper "green" construction materials and afforestation of urban and rural areas.

\section{REFERENCES}

[1] Aniello, C. (1995). Mapping Micro-urban Heat Islands Using LANDSAT TM and a GIS. Computers \& Geosciences, 21(8), 965-967. https://doi.org/10.1016/0098-3004(95)00033-5

[2] Emery, J., Oke, T., \& Roth, M. (1989). Satellite-Derived Urban Heat Islands from Three Coastal Cities and the Utilization of Such Data in Urban Climatology. International Journal of Remote Sensing, 10, 1699-1720. https://doi.org/10.1080/01431168908904002

[3] Oke, T. R. (1987). Boundary layer climates, $2^{\text {nd }}$. Methuen.
[4] Voogt, J. A. \& Oke, T. R. (2003). Thermal remote sensing of urban climates. Remote Sensing Environmental, 86, 370384. https://doi.org/10.1016/S0034-4257(03)00079-8

[5] Jimenez-Munoz, J. C. \& Sobrino, J. (2004). A generalized single-channel method for retrieving land surface temperature from remote sensing data. Journal of Geophysical Research, 108(22), 4688.

[6] Oke, T. R. (2006). Initial Guidance to Obtain Representative Meteorological Observations at Urban Sites. World Meteorological Organization, Instruments and Observing Methods, IOM Report No. 81, WMO/TD-No. 1250.

[7] Babić, S., Deluka-Tibljaš, A., Cuculić, M., \& Šurdonja, S. (2012). Analysis of pavement surface heating in urban areas. Građevinar, 64(2), 127-134.

[8] Voogt, J. A. (2002). Urban Heat Island (Chapter), Encyclopedia of Global Environmental Change (Munn, T., ed.), 3, 660-666, Chichester, Wiley.

[9] Nuruzzaman, Md. (2015). Urban Heat Island: Causes, Effects and Mitigation Measures - A Review. International Journal of Environmental Monitoring and Analysis, 3(2), 6773. https://doi.org/10.11648/j.jjema.20150302.15

[10] De Munck, C., Pigeon, G., Masson, V., Meunier, F., Bousquet, P., Tremeac, B., Merchat, M., Poeuf, P., \& Marchadier, C. (2013). How much can air conditioning increase air temperatures for a city like Paris, France? International Journal of Climatology, 33(1), 210-227. https://doi.org/10.1002/joc.3415

[11] Oke, T. R. (1997). Urban Environments - The Surface Climates of Canada. McGill-Queen's University Oress, Montreal.

[12] Environmental Fluid Dynamics - LUMPS Project,http://mech.utah.edu/ pardyjak. (Accessed on 10.06.2016)

[13] The URBANFLUXES idea, http://urbanfluxes.eu (Accessed on 10.06.2016)

[14] Šiljković, Ž. \& Čuljak, M. (2015). Transformation of Rural Settlements of the City of Mostar in the Second Half of the Twentieth Century. Geoadria, 20(1), 41-52. https://doi.org/10.15291/geoadria.30

[15] Radusin, S., Oprašić, S., Cero, M., Abdurahmanović, I., \& Vukmir, G. (2003). Drugi nacionalni izvještaj Bosne i Hercegovine u skladu s okvirnom konvencijom ujedinjenih nacija.

[16] "Bosnia and Herzegovina" in Geo-Data: The World Geographical Encyclopedia, Gale, 2003.

[17] Climate Summary for Mostar, Meteorological Institute of Bosnia and Herzegovina, Sarajevo, 2015.

[18] Federalni zavod za statistiku http://www.fzs.ba

[19] World Meteorological Organization, World Weather Information Service, 2015. 
[20] Extremes, Meteorological Institute of Bosnia and Herzegovina, Sarajevo, 2016.

[21] Deutscher Wetterdienst "Klimatafel von Mostar / Bosnien und Herzegowina" Baseline climate means (1961-1990) from stations all over the world (in German). 2000.

[22] Tomlison, J. C., Chapman, L., Thornes, J. E., \& Baker, C. (2011). Remote sensing land surface temperature for meteorology and climatology: a review. Meteorological Applications, 18(3), 296-306. https://doi.org/10.1002/met.287

[23] Rao, P. K. (1972). Remote sensing of urban heat islands from an environmental satellite. Bulletin of the American Meteorological Society, 53, 647- 648.

[24] Leder, T. D., Leder, N., \& Hećimović, Ž. (2016).Split Metropolitan area surface temperature assessment with remote sensing method. Građevinar, 68(11), 895-905. https://doi.org/10.14256/JCE.1661.2016

[25] Praćenje i ocjena klime u 2015. godini - Climate monitoring and Assesment for 2015, Državni hidrometeorološki zavod (Pandžić, K., Lisko, T. ed.), Zagreb, 2016.

[26] Barsi, J. A., Schott, J. R., Palluconi, F. D., \& Hook, S. J. (2005). Validation of a Web-Based Atmospheric Correction Tool for Single Thermal Band Instruments, Earth Observing Systems X, ed. Butler, J. J., Proceedings of SPIE Vol. 5882. http://atmcorr.gsfc.nasa.gov (Accessed on 10.06.2016)

[27] Schott, J. R., Brown, S. D., Barsi, J. A. (2004). Calibration of Thermal Infrared (TIR) Sensors, In J. Luvall \& D. Quattrochi (Eds.). Thermal Remote Sensing in Land Surface Processes. United Kingdom, Taylor \& Francis. https://doi.org/10.1201/9780203502174-c11

[28] Barsi, J. A., Schott, J. R., Palluconi, F. D., Helder, D. L., Hook, S. J., Markham, B. L., Chander, G., O’Donnell, E. M. (2003). Landsat TM and ETM+ Thermal Band Calibration. Canadian Journal of Remote Sensing, 28(2), 141-153. https://doi.org/10.5589/m02-087

[29] USGS: Landsat 8 (L8) Data Users Habdbook, Department of the Interior U.S. Geological Survey, EROS, Sioux Falls, South Dakota, (2015) http://landsat.usgs.gov (Accessed on 10.06.2016)

[30] Lin, B. (2014). Earth Radiation Budget, Top of Atmosphere Radiation in Encyclopedia of remote sensing (Njoku, E. G. ed.), Springer, 145-146. https://doi.org/10.1007/978-0-387-36699-9_39

[31] Uysal, M. \& Polat, N. (2015). An investigation of the relationship between land surface temperatures and biophysical indices retrieved from Landsat TM in Afyonkarahisar (Turkey). Technical Gazette, 22(1), 177181. https://doi.org/10.17559/TV-20140514212110

\section{Contact information:}

Tea DUPLANČIĆ LEDER, PhD, Full Professor

Faculty of Civil Engineering, Architecture and Geodesy,

University of Split,

Matice hrvatske 15

21000 Split, Croatia

E-mail: tleder@gradst.hr

Nenad LEDER, PhD, Assistant Professor

Faculty of Maritime Studies,

University of Split,

Ruđera Boškovića 37,

21000 Split, Croatia

E-mail: nenad.leder@pfst.hr 